\title{
Face masks use during the COVID-19 pandemic: Differences in attitudes and practices between medical and non-medical students. A survey of 2256 students in Poland
}

\author{
Łukasz Matusiak ${ }^{1, A-E}$, Marta Szepietowska ${ }^{2, A-D}$, Piotr Krajewski ${ }^{1, A, B, D, F}$, Rafał Białynicki-Birula, ${ }^{1, A, B, D-F}$, Jacek Szepietowski ${ }^{1, A-F}$ \\ 1 Department of Dermatology, Venereology and Allergology, Wroclaw Medical University, Poland \\ ${ }^{2}$ Student Research Group of Experimental Dermatology, Department of Dermatology, Venereology and Allergology, Wroclaw Medical University, Poland \\ A - research concept and design; $B$ - collection and/or assembly of data; $C$ - data analysis and interpretation; \\ $D$ - writing the article; $E$ - critical revision of the article; $F$ - final approval of the article
}

Address for correspondence

Jacek Szepietowski

E-mail: jacek.szepietowski@umed.wroc.pl

Funding sources

None declared

Conflict of interest

None declared

Received on May 7, 2020

Reviewed on May 17, 2020

Accepted on August 11, 2020

Published online on October 30, 2020

Cite as

Matusiak Ł, Szepietowska M, Krajewski P, Białynicki-Birula R, Szepietowski J. Face masks use during the COVID-19 pandemic Differences in attitudes and practices between medical and non-medical students. A survey of 2256 students in Poland. Adv Clin Exp Med. 2020;29(10):1201-1203.

doi:10.17219/acem/126295

DOI

10.17219/acem/126295

Copyright

Copyright by Author(s)

This is an article distributed under the terms of the

Creative Commons Attribution 3.0 Unported (CC BY 3.0)

(https://creativecommons.org/licenses/by/3.0/)

\begin{abstract}
Background. The use of face masks during the COVID-19 pandemic became ubiquitous. Such masks are believed to be effective in prevention of respiratory viral transmission.

Objectives. The study was undertaken to assess the use of face masks among students during the COVID-19 pandemic, with focus on similarities and differences between medical and non-medical students.

Material and methods. The study was based on the specially designed survey. The questionnaire, after consultation with 10 students, was created using Google Forms and posted on numerous Facebook groups for students in Poland. The recall period of the questionnaire was the previous 7 days. In $48 \mathrm{~h}, 2,315$ answers were obtained. Fifty-nine questionnaires were excluded due to data incompleteness and failure to fulfil inclusion criteria. Therefore, 2,256 surveys (97.5\%) were considered for final analysis.

Results. Medical students showed significantly different attitudes and practices concerning the use of face masks. Medical students used face masks more commonly and for longer periods of time. Moreover, they wore single-use masks more often and less frequently re-used them. Also, multiple use of single-use face masks and masks decontamination procedures were less common among medical students.
\end{abstract}

Conclusions. We suggest that medical students might be of help in educational campaigns for general public on proper use of face protection.

Key words: COVID-19, coronavirus, face masks, medical students 


\section{Introduction}

The COVID-19 pandemic resulted in increased use of face protection. ${ }^{1-3}$ Face masks are believed to be effective in prevention of respiratory viral transmission. ${ }^{2}$ This may be of importance for general health policy.

This study was undertaken to assess the use of face masks among students during the COVID-19 pandemic, with focus on similarities and differences between medical and non-medical students.

\section{Material and methods}

The study was based on the specially designed survey. The questionnaire was developed based on the interviews with 10 students. All the relevant issues raised during the interviews were put up together and considered for the questionnaire. Then, the proposed question naire was assessed by 2 independent experts in such studies, who gave their comments on the proper wording and understanding of each question. The recall period of the questionnaire was the previous 7 days. The final survey was created using Google Forms and posted on numerous Facebook groups for students in Poland. The data were collected during $48 \mathrm{~h}$ between April 12 (10:00 PM) and April 14, 2020 (10:00 PM). At that time, the use of face masks in Poland was not mandatory. Based on the decision of Polish government (from March 11, 2020) regular activities of schools and universities were suspended, and only tele-education was allowed and advised. A total of 2,315 answers were obtained. Due to the incompleteness of the data and failure to fulfil inclusion criteria (not completed by students), 59 questionnaires were excluded. Therefore, 2,256 surveys (97.5\%) were considered for final analysis. The selected responses were subject to statistical analysis (STATISTICA v. 13; StatSoft Inc., Tulsa, USA). The $X^{2}$ test was applied to determine statistical differences between the groups of medical and non-medical students. The resulting $\mathrm{p}$-values were considered significant if $\mathrm{p}<0.05$.

\section{Results}

Among 2,256 respondent, there were 1,170 (51.9\%) medical students and 1,086 (48.1\%) students of other faculties, not related to health sciences (non-medical students). The mean age of the group was $20.9 \pm 1.6$ years (age range: 19-27 years). A total of 1,366 students (60.5\%) declared using face masks. Medical students wore face protection significantly more often $(\mathrm{p}=0.02)$ than non-medical students $(62.8 \%$ and $58.1 \%$, respectively) (Table 1$)$. More than $1 / 3$ of students $(34.3 \%)$ used several types of face masks. Wearing various types of face protection was significantly more common $(\mathrm{p}=0.03)$ in medical students $(35.1 \%)$ than in students of other faculties (33.4\%) (Table 1). Out of all types of face masks, cloth masks (46.2\%) appeared to be worn most frequently, followed by surgical masks (39.3\%) and respirators (N95 and FFPs (filtering face pieces); 13.3\%), while other types were used only sporadically (Table 1$)$. Medical students significantly more often $(\mathrm{p}<0.001)$ used surgical masks. In contrast, non-medical students wore cloth masks more commonly ( $\mathrm{p}<0.001)$. There was no difference in the frequency of wearing other types of face masks between the 2 groups (Table 1). Single-use masks

Table 1. Face mask use among medical and non-medical students during the COVID-19 pandemic

\begin{tabular}{|c|c|c|c|c|}
\hline Variable & Total & Medical students & Non-medical students & $p$-value* \\
\hline $\begin{array}{l}\text { Students using face masks } \\
\text { yes } \\
\text { no }\end{array}$ & $\begin{array}{c}1366(60.5 \%) \\
890(39.5 \%)\end{array}$ & $\begin{array}{l}735(62.8 \%) \\
435(37.2 \%)\end{array}$ & $\begin{array}{l}631(58.1 \%) \\
455(41.9 \%)\end{array}$ & 0.02 \\
\hline $\begin{array}{l}\text { Types of face masks used } \\
\text { surgical masks } \\
\text { cloth masks } \\
\text { respirators (N95 + FFP) } \\
\text { half-face elastometric respirator } \\
\text { full-face respirator }\end{array}$ & $\begin{array}{c}744(39.3 \%) \\
874(46.2 \%) \\
252(13.3 \%) \\
16(0.8 \%) \\
8(0.4 \%)\end{array}$ & $\begin{array}{c}435(42.4 \%) \\
440(42.9 \%) \\
141(13.7 \%) \\
7(0.7 \%) \\
3(0.3 \%)\end{array}$ & $\begin{array}{c}309(35.6 \%) \\
434(50.0 \%) \\
111(12.8 \%) \\
9(1.0 \%) \\
5(0.6 \%)\end{array}$ & $\begin{array}{c}<0.001 \\
<0.001 \\
0.45 \\
0.42 \\
0.35\end{array}$ \\
\hline Single-use face masks worn & $996(52.6 \%)$ & $576(56.1 \%)$ & $420(48.4 \%)$ & $<0.001$ \\
\hline Several types of face masks used & $469(34.3 \%)$ & $258(35.1 \%)$ & $211(33.4 \%)$ & 0.03 \\
\hline $\begin{array}{l}\text { Duration of face masks used per day } \\
\text { up to } 1 \mathrm{~h} \\
\text { up to } 2 \mathrm{~h} \\
\text { up to } 3 \mathrm{~h} \\
\text { more than } 5 \mathrm{~h}\end{array}$ & $\begin{array}{c}689(50.4 \%) \\
1145(83.8 \%) \\
1259(92.2 \%) \\
56(4.1 \%)\end{array}$ & $\begin{array}{l}354(48.2 \%) \\
600(81.6 \%) \\
665(90.5 \%) \\
37(5.0 \%)\end{array}$ & $\begin{array}{c}355(56.3 \%) \\
545(86.4 \%) \\
594(94.1 \%) \\
19(3.0 \%)\end{array}$ & $\begin{array}{c}0.06 \\
\mathbf{0 . 0 0 9} \\
\mathbf{0 . 0 0 4} \\
0.06\end{array}$ \\
\hline Multiple use of single-use face masks & $332(24.3 \%)$ & $172(23.4 \%)$ & $160(25.5 \%)$ & 0.02 \\
\hline Decontamination of face masks (all types) & $1004(73.5 \%)$ & $506(60.8 \%)$ & $498(78.9 \%)$ & $<0.0001$ \\
\hline Decontamination of multi-use face masks & $1267(92.8 \%)$ & $678(92.2 \%)$ & $589(93.3 \%)$ & 0.43 \\
\hline
\end{tabular}

p-values in bold are statistically significant. 
were used significantly more often $(\mathrm{p}<0.001)$ by medical students than non-medical ones $(56.1 \%$ and $48.4 \%$, respectively). Consequently, decontamination of face masks was markedly a more common procedure $(\mathrm{p}<0.0001)$ among non-medical students; however, no differences were noticed in terms of multi-use masks (Table 1). As for the duration of the daily face mask wear, non-medical students used them more commonly for shorter periods during the day (less than $1 \mathrm{~h}$ ). By contrast, medical students significantly more often used face protection for longer periods of time ( $p=0.009$ for cut-off point of $2 \mathrm{~h}$ per day and $\mathrm{p}=0.004$ for cut-off point of $3 \mathrm{~h}$ per day) (Table 1 ). Some students (24.3\%) used single-use masks several times. The multiple use of disposable respiratory protective devices was significantly less frequent $(\mathrm{p}=0.02)$ in medical students' group (Table 1).

\section{Discussion}

Since the outbreak of COVID-19, in Asian countries, especially in China, the use of facial masks has become ubiquitous. ${ }^{4,5}$ People at low risk of infection were instructed to use disposable masks for medical usage and even people at very low risk were recommended to use non-medical masks, such as cloth masks. ${ }^{1,5}$ With the spread of infection, as a protective action, on March 11, 2020, the Polish government decided to suspend regular activities in all schools, including universities. Centers for Disease Control (CDC; Atlanta, USA) advised to screen mouth and nose with a cloth face cover when around others during the COVID-19 pandemic. ${ }^{6}$ In our country, more and more people decided to wear face protection when they were outdoors. On the April 9, 2020, the Polish Ministry of Health announced that starting from the April 16, 2020 covering the nose and mouth when being in public space was obligatory. It is worth to note that our study was performed when wearing the face masks by general population was not obligatory.

Differences in the health-related attitudes, behaviors and practices between medical and non-medical students have been previously documented..$^{7-9}$ To the best of our knowledge, this is a first report on students' attitudes concerning the use of face masks during viral pandemic. It is worth mentioning that the conditions for both groups were more or less similar (all universities were closed; medical students did not attend clinical classes). Our results clearly showed that medical students used face masks more commonly and for longer periods of time. Moreover, they wore single-use masks more often and less frequently reused them. It is not surprising that the decontamination procedures of the masks were significantly less common among medical students, since they used more disposable masks. Based on our results, we suggest that medical students, most probably due to their awareness, knowledge and personal interest, might be of help in educational campaigns for general public on proper use of face protection.

\section{ORCID iDs}

Łukasz Matusiak (D) https://orcid.org/0000-0003-2067-4929

Marta Szepietowska (D) https://orcid.org/0000-0002-4843-4073

Piotr Krajewski (D) https://orcid.org/0000-0003-4722-8531

Rafał Białynicki-Birula (D) https://orcid.org/0000-0002-2603-4220

Jacek Szepietowski (D) https://orcid.org/0000-0003-0766-6342

\section{References}

1. Feng S, Shen C, Xia N, Song W, Fan M, Cowling BJ. Rational use of face masks in the COVID-19 pandemic. Lancet RespirMed. 2020; 8(5):434-436.

2. Kirby T. Australian government releases face masks to protect against coronavirus. Lancet Respir Med. 2020;8(3):239.

3. Stone TE, Kunaviktikul W, Omura M, Petrini M. Facemasks and the Covid 19 pandemic: What advice should health professionals be giving the general public about the wearing of facemasks? Nurs Health Sci. 2020;22(2):339-342.

4. Javid B, Weekes MP, Matheson NJ. Covid-19: Should the public wear face masks? BMJ. 2020;369:m1442.

5. Wang MW, Zhou MY, Ji GH, et al. Mask crisis during the COVID-19 outbreak. Eur Rev Med Pharmacol Sci. 2020;24(6):3397-3399.

6. Control of Diseases. How to protect yourself. https://www.cdc.gov/ coronavirus/2019-ncov/prevent-getting-sick/prevention-H.pdf. Accessed April 26, 2020.

7. Bayramoglu Tepe N, Ozcorekci O. Knowledge about the human papillomavirus among high school and university students: A comprehensive questionnaire study from southeast Turkey. JObstet Gynaecol Res. 2020;46(6):907-916.

8. Hong DW, Lin XJ, Wiegand A, YuH. Knowledge of and attitudes towards erosive tooth wear among students of two Chinese universities. BMC Oral Health. 2020;20(1):110.

9. Liu H, Yang $Y, X u$ D, et al. Investigation and comparison of nutritional supplement use, knowledge, and attitudes in medical and non-medical students in China. Nutrients. 2018;10(11):1810. 